University of Nebraska - Lincoln

DigitalCommons@University of Nebraska - Lincoln

Papers in Plant Pathology

Plant Pathology Department

2010

Soil and root populations of fluorescent Pseudomonas spp. associated with seedlings and field-grown plants are affected by sorghum genotype

Deanna L. Funnell-Harris

USDA-ARS, Deanna.Funnell-Harris@ars.usda.gov

Jeffrey F. Pedersen

USDA-ARS, jpedersen1@unl.edu

Scott E. Sattler

USDA-ARS, Scott.Sattler@ars.usda.gov

Follow this and additional works at: http://digitalcommons.unl.edu/plantpathpapers

Part of the Other Plant Sciences Commons, Plant Biology Commons, and the Plant Pathology Commons

Funnell-Harris, Deanna L.; Pedersen, Jeffrey F.; and Sattler, Scott E., "Soil and root populations of fluorescent Pseudomonas spp. associated with seedlings and field-grown plants are affected by sorghum genotype" (2010). Papers in Plant Pathology. 452.

http://digitalcommons.unl.edu/plantpathpapers/452

This Article is brought to you for free and open access by the Plant Pathology Department at DigitalCommons@University of Nebraska - Lincoln. It has been accepted for inclusion in Papers in Plant Pathology by an authorized administrator of DigitalCommons@University of Nebraska - Lincoln. 


\title{
Soil and root populations of fluorescent Pseudomonas spp. associated with seedlings and field-grown plants are affected by sorghum genotype
}

\author{
Deanna L. Funnell-Harris • Jeffrey F. Pedersen • \\ Scott E. Sattler
}

Received: 2 December 2009 / Accepted: 11 May 2010/Published online: 27 May 2010

(C) US Government 2010

\begin{abstract}
Sorghum [Sorghum bicolor (L.) Moench] is valued for bioenergy, feed and food. Potential of sorghum genotypes to support differing populations of root- and soil-associated fluorescent Pseudomonas spp. or Fusarium spp., in two soils, was assessed. Culturable pseudomonads were enumerated from roots and soil of sorghum (Redlan and RTx433) and wheat (Lewjain) seedlings repeatedly grown in cycled soils in the growth chamber. Pseudomonads and Fusarium spp. were assessed from roots and soil of field-grown sorghum along with biological control traits hydrogen cyanide (HCN) and 2,4-diacetylphlorogluconol $(p h l)$ production. After four 4-week cycles, soil associated with Redlan seedlings had greater
\end{abstract}

Responsible Editor: Petra Marschner.

D. L. Funnell-Harris $(\bowtie) \cdot$ J. F. Pedersen $\cdot$ S. E. Sattler Grain, Forage and Bioenergy Research Unit, USDA-ARS, 314 BioChem Hall, UNL-East Campus,

Lincoln, NE 68583-0737, USA

e-mail: Deanna.Funnell-Harris@ars.usda.gov

D. L. Funnell-Harris

Department of Plant Pathology, University of Nebraska, Lincoln, NE, USA

J. F. Pedersen · S. E. Sattler

Department of Agronomy and Horticulture,

University of Nebraska,

Lincoln, NE, USA numbers of fluorescent pseudomonads than Lewjain. In dryland field conditions, RTx433 roots had greater numbers of pseudomonads than Redlan before anthesis but similar numbers after. There were no differences in numbers of pseudomonads from dryland soil or roots or soil of irrigated plants. Percentages of $\mathrm{HCN}$-producing root isolates and phl soil isolates declined on irrigated Redlan plants, but percentages of HCN-producers increased in dryland conditions. Redlan roots had greater percentages of Fusarium isolates in the Gibberella fujikuroi complex. Results indicated that sorghum genotype affected rootassociated populations of fluorescent Pseudomonas spp. and Fusarium spp. across soil environments.

Keywords 2,4-diacetylphloroglucinol · Fusarium spp. Gibberella fujikuroi species complex · Rhizosphere · Pseudomonas spp. S Sorghum bicolor

$\begin{array}{ll}\text { Abbreviations } \\ \text { 2,4- } & \text { 2,4-diacetylphloroglucinol } \\ \text { DAPG } & \\ \text { DCPA } & \text { dichloran chloramphenicol peptone agar } \\ \text { PCNB } & \text { pentachloronitrobenzene } \\ \text { PDA } & \text { potato dextrose agar } \\ \text { Phl } & \text { 2,4-diacetylphloroglucinol gene } \\ \text { PCA } & \text { phenazine-1-carboxylic acid gene } \\ \text { TSA } & \text { Tryptic soy agar }\end{array}$




\section{Introduction}

Sorghum is the second most important US grain crop for animal feed, by acreage, and is gaining attention for its usability as feedstock for biofuel production (Sarath et al. 2008). Worldwide, sorghum is the fifth most commonly grown cereal, is gluten-free, and provides nutrients and protective phytochemicals unique among grasses (Awika and Rooney 2004; Rai et al. 1999). This $C_{4}$ crop is drought and heat tolerant, and therefore can be grown in marginal areas and is commonly included in intercropping and rotation cropping systems (Dhuyvetter et al. 1996; Sarath et al. 2008; Smith and Frederiksen 2000). Improved cultivars and the ability to generate hybrids have resulted in increased yields, even under dryland and subsistence farming conditions (Rai et al. 1999). Because of the value of sorghum for bioenergy feed stock, animal feed and a food staple in cultures worldwide, it is important to identify practical and low cost methods for prevention and control of diseases.

The use of plant genotype has been proposed as a means to increase populations of plant growth promoting rhizobacteria or microorganisms antagonistic to soil-borne pathogens (Cook 2007; Picard and Bosco 2008). Cultivar selection was one method included in cultural control of the devastating wheat disease, takeall (Cook 2007). It was demonstrated that at least one wheat cultivar, Lewjain, had the ability to support large numbers of fluorescent Pseudomonas spp. that produced 2,4-diacetylphloroglucinol (2,4-DAPG), a compound that can suppress infection by some Gaeumannomyces graminis var tritici isolates capable of causing take-all on wheat seedlings in growth chamber bioassays (Mazzola et al. 1995, 2004). These reports indicate that careful selection of plant genotype may provide protection against fungal diseases by way of enhancing populations of beneficial rhizobacteria (Mazzola et al. 2004).

Pseudomonas fluorescens isolated from native soils had been shown to increase field emergence of seedlings when applied to sorghum grain infected with Fusarium moniliforme (Raju et al. 1999). Additionally, seed treatment with a soil isolate of Pseudomonas chlororaphis reduced the sorghum stalk disease charcoal rot, caused by the fungus Macrophomina phaseolina, as well as incidences of lodging (Das et al. 2008). Fusarium spp., including several species within the Gibberella fujikuroi species complex (also known as F. moniliforme) have been reported to cause root and stalk diseases of sorghum (Idris et al. 2007; Petrovic et al. 2009; Tesso et al. 2005). Thus, our interests included examining sorghum genotypes for modification of root and soil populations of potentially beneficial and pathogenic microorganisms.

Outside of wheat, there has been little research examining genotype-specific root associations between grasses and fluorescent Pseudomonas spp. One study suggested that maize hybrids exhibit greater ability to select for "elite" Pseudomonas spp. (as determined by 2,4-DAPG-production and potential for greater root colonization) than parental cultivars (Picard and Bosco 2006). Recently, we provided evidence suggesting that when sorghum seedlings preceded wheat seedlings in a crop sequence, sorghum genotype influenced the characteristics of fluorescent Pseudomonas spp. populations in bulk soil (Funnell-Harris et al. 2008). That root exudates of sorghum genotypes Redlan and RTx433 differed had been shown by studies in which seedlings differentially produced the benzoquinone root exudate, sorgoleone: of 25 genotypes tested, Redlan produced the greatest amount while RTx 433 produced the least (approx. 18 versus $1 \mathrm{mg}$ per $\mathrm{g}$ root fresh weight) (Nimbal et al. 1996). Although this compound is technically challenging to detect in rhizospheres of soil-grown plants (Weidenhamer 2005), previous studies have suggested that genotypespecific differences in sorghum root exudates may affect soil microbial communities (Kipe-Nolt et al. 1985; Funnell-Harris et al. 2008). The turnover of applied sorgoleone to native soils indicated that microorganisms utilize this compound as an energy source, which suggests a possible mechanism of how sorgoleone may influence soil microbial communities (Gimsing et al. 2009).

Because sorgoleone is potentially allelopathic, differences in sorgoleone levels among sorghum genotypes may affect growth of plants in cropping systems (Einhellig and Souza 1992; Roth et al. 2000). During cycling of seedlings in growth chamber bioassays, wheat cultivar Lewjain preceded or succeeded cycling of sorghum genotypes RTx433 and Redlan, and changes in characteristics of fluorescent Pseudomonas spp. were monitored in soils at the end of each cycle (Funnell-Harris et al. 2008). Traits 
potentially involved in biological control, including 2,4-DAPG, indirectly detected by PCR amplification of $p h l D$ gene $(p h l)$, and hydrogen cyanide production $(\mathrm{HCN})$, detected by a colorimetric assay, were assessed (Funnell-Harris et al. 2008; Raaijmakers et al. 1997). This study indicated that percentage of Pseudomonas isolates producing HCN increased through cycling of seedlings while those with $p h l$ declined except for those associated with soil planted with Redlan, in which an increase in percent of isolates with this trait was observed (Funnell-Harris et al. 2008).

Herein we examined the effect of sorghum genotypes on populations of root-associated and soil fluorescent Pseudomonas spp., Fusarium spp., and another fungal genus, Alternaria, which also includes species pathogenic to sorghum (Waniska et al. 2001). No reports of numbers or characteristics of fluorescent Pseudomonas spp. in rhizospheres of differing sorghum genotypes, grown in different soils, are presently known. Previously, there have not been any reports monitoring potential fungal pathogens of field-grown sorghum throughout the growing season. Total culturable bacteria and fungi, and fluorescent Pseudomonas spp., were enumerated from roots, which included rhizosphere soil, and bulk soil of seedlings of sorghum genotypes Redlan and RTx433 and wheat cv. Lewjain, which served as the positive control for phl. Soils obtained from two locations (Lincoln and Ithaca, NE) were planted under these controlled conditions. The same sorghum genotypes also were planted at fields in Lincoln, which were dryland, and Ithaca, which were irrigated; comparison of results from growth chamber seedlings and fieldgrown plants could indicate differences potentially due to soil characteristics or environmental effects. Field-grown plants were assessed throughout the growing season for root-associated and soil microorganisms, including fluorescent Pseudomonas spp. and Fusarium and Alternaria spp.

\section{Materials and methods}

Bacterial sources and culture

Pseudomonas fluorescens isolate Q2-87 (Bangera and Thomashow 1999) was obtained from M. Mazzola (USDA-ARS, Wenatchee, WA) and isolate 2-79
(Mavrodi et al. 1998) was obtained from L. Thomashow (USDA-ARS, Pullman). P. fluorescens isolate NRRL B-23932 (also known as "Pf-5") was obtained from USDA-ARS, National Center for Agricultural Utilization Research (NCAUR), Peoria, IL. Bacterial isolates were maintained in culture on Kings B (KB) agar (Cowan 1974) and stored at $-80^{\circ} \mathrm{C}$ in $44 \%$ nutrient broth, $0.8 \%$ yeast extract [Becton, Dickinson and Co. (BD), Sparks, MO USA], 0.2\% glucose and $45 \%$ glycerol.

Media for enumeration of microorganisms

For preparation of media and dilution suspensions, distilled water was purified using a four filter (one carbon and three deionizing) general chemistry polishing system and a hollow fiber final filter with $0.2 \mu \mathrm{m}$ pore size to remove bacteria (Labconco, Kansas City, MO). Total culturable bacterial colony forming units (cfu) per gram of soil or root samples was determined by plating suspensions of each onto one-tenth strength tryptic soy agar [TSA; prepared with tryptic soy broth (BD)]. Fluorescent Pseudomonas spp. were isolated by plating soil or root suspensions onto KB agar amended with ampicillin (100 $\left.\mu \mathrm{g} \mathrm{ml}^{-1}\right)$, cycloheximide $\left(100 \mu \mathrm{g} \mathrm{ml}^{-1}\right)$ and chloramphenicol $\left(13 \mu \mathrm{g} \mathrm{ml}{ }^{-1}\right)\left(\mathrm{KB}^{+}\right.$; Simon and Ridge 1974). Following examination under ultraviolet light, fluorescing colonies were transferred to $\mathrm{KB}$ agar and, after growth of colonies, fluorescence was confirmed.

To estimate total culturable fungal and oomycete cfu per gram of soil or root samples, suspensions were plated onto one-fifth strength potato dextrose agar [PDA; prepared with potato dextrose broth (BD)] amended with $0.04 \%$ Triton X-100 (Calbiochem, EMD Biosciences, San Diego) and $50 \mathrm{mg} \mathrm{l}^{-1}$ ampicillin. Two semi-selective peptone agar media were used to estimate numbers of Fusarium and Alternaria spp. Dichloran chloramphenicol peptone agar (DCPA) was amended with the fungicide dichloran and chloramphenicol and was semi-selective for Fusarium and Alternaria and other dark-spored hyphomycetes (Andrews and Pitt 1986). PCNB, semi-selective for Fusarium spp., was amended with the fungicide pentachloronitrobenzene (added in its commercial formulation, "Terrachlor," Uniroyal Co., Middlebury, CT) and streptomycin (Nash and Snyder 1962). In previous studies, Alternaria spp. were recovered at a 
much reduced rate, or not all from, from grain or leaf samples plated onto PCNB medium as compared with DCPA (Funnell and Pedersen 2006). Dichloran and antibiotics were purchased from Sigma-Aldrich (St. Louis).

Growth chamber wheat and sorghum seedling cycling

For plant culture in growth chamber, Ray Leach "Cone-tainers TM" (Stuewe \& Sons, Inc., Corvalis, OR), which are conical-shaped plastic cells, $3.8 \mathrm{~cm}$ diameter at the top opening, by $21 \mathrm{~cm}$ long with 4 drainage holes at the bottom, were used. Individual cells, intended to hold one plant each, were placed in rectangular trays that hold 98 cells in a $7 \times 14$ grid. From this point forward, the contents (plant and soil) of one cell will be considered one plant and cells will be referred to as pots. For growth chamber assays, soil was collected twice from post-harvest sorghum fields at University of Nebraska (UNL), Lincoln in 2004 and once at Ithaca in 2006 and again in 2007. To collect field soil, approx. $2 \mathrm{~cm}$ soil and debris was removed and discarded from surface then approx. one liter of soil was collected, using a shovel, to approx. $15 \mathrm{~cm}$ below original soil surface. Soil collection was random across sorghum fields. Approx. 15 liters of soil was obtained from each collection. Soil was mixed by hand prior to sampling and distributing into pots. Soil at Lincoln was a Kennebec silt loam, a finesilty, mixed, superactive, mesic Cumulic Hapladolls. Fields at Lincoln were not irrigated. Soil at Ithaca was a Tomek silt loam, a fine, smectitic, mesic Pachic Ariguidolls and the fields were irrigated.

Seeds of sorghum [Sorghum bicolor (L.) Moench] genotypes Redlan and RTx433 were produced in greenhouses. In our experience, greenhouse-grown sorghum seeds have very low levels of endophytic fungi (less than $0.2 \%$ ). Seeds of wheat cultivar Lewjain (Triticum aestivum L.) were obtained from K. Garland-Campbell (USDA-ARS, Pullman, WA). For preparation of pots and planting of seeds, workers wore gloves. Prior to planting, soil was assessed for total numbers of culturable bacteria and fungi and oomycetes, and numbers of fluorescent Pseudomonas spp. per gram of soil using dilution plating of soil suspensions (see below). Four cycles (labeled 1, 2, 3 and 4) were conducted for each experiment. For cycle 1 , soil was distributed into pots and seeds of either wheat cultivar Lewjain or of sorghum genotypes
Redlan or RTx433 were sown onto the soil surface and covered with soil then vermiculite. Twenty-eight pots of wheat and of each sorghum genotype were planted and rows of seven pots were alternated by plant genotype. Each pot was watered with 10 to $15 \mathrm{ml}$ of sterilized one-third strength Hoagland's solution lacking minerals prepared with filterpurified water. Plants were watered three times per week with 10 to $15 \mathrm{ml}$ sterile filter-purified water, which prevented additional inputs of salts, minerals and microorganisms. After germination, seedlings were culled to one plant per pot and maintained in a growth chamber at $22^{\circ} \mathrm{C}$ with $12 \mathrm{~h}$ light. Plants were grown for 4 weeks under these conditions (Landa et al. 2003; Mazzola et al. 2004; Picard et al. 2008), as it has been our experience that most grain sorghum genotypes tested have been able to grow without obvious stress in the confined quarters of Conetainers $^{\mathrm{TM}}$ for up to approx. 4 weeks. After 4 weeks, seven randomly chosen plants of wheat and of each sorghum genotype were analyzed for fresh weight of aerial parts and for root and soil populations of microorganisms. For each plant, total fresh weight of stalk and leaves removed at soil level was determined. To obtain root sample, soil was carefully removed from the root system except that which was tightly adhering. The total fresh weight of roots plus rhizosphere soil from each plant was recorded for cycle 1. Using surface-sterilized scissors, roots were snipped into approx. $1 \mathrm{~cm}$ lengths. One root sample, up to $1 \mathrm{~g}$, for each plant, was prepared. Root samples likely included rhizosphere, rhizoplane and endophytic microorganisms (Compant et al. 2010). Number of fluorescent Pseudomonas spp. cfu per gram for each root sample was determined by suspending the sample in sterile purified water, performing dilutions, then plating three aliquots of each dilution onto $\mathrm{KB}^{+}$ agar. Soil that had been easily removed from the root system, as well as any remaining soil from the pot, was combined, and two approx. $1 \mathrm{~g}$ samples were prepared. Each soil sample was suspended in sterile purified water. Dilutions were performed then plated onto TSA for determination of total bacteria, PDA for enumeration of total fungi and oomycetes and $\mathrm{KB}^{+}$ for determination of numbers of fluorescent Pseudomonas spp. Root and soil suspensions prepared from a plant were transferred to agar media at the same time and, generally, all plants were processed on the same day. 
On the same or the following day, the next cycle was planted by using soil in the remaining pots. Above-ground plant parts were removed. Soils from each plant of the same genotype were combined in a surface-sterilized tub and the root masses were gently broken apart and distributed throughout the soil, which was returned to the same pots. This was repeated for each plant genotype. Pots were replanted with the same species or genotype as in the previous cycle. Planting and maintenance of plants, and analyses of plants and soil, were as described in the previous paragraph. This was continued until cycle 4 was completed. The experiment was conducted twice using soil from each location (Lincoln or Ithaca). Treatments were roots or soil for each plant genotype. Individual plants served as repetitions within an experiment and each experiment was considered a block.

\section{Experimental design and analyses}

The growth chamber study was analyzed as two experiments, one using soil collected at Lincoln and one using soil collected at Ithaca using the PROC MIXED procedure of SAS (SAS, 2000-2004). Cycle $(1,2,3,4)$, genotype (Lewjain, Redlan, RTx433), and their interaction were considered fixed effects in the MODEL. Each experiment was a $4 \times 3$ factorial conducted in a randomized complete block with two replications. Within each replication, dependent variable response was measured in seven individual pots. CLASS variables were therefore replication, genotype, cycle, and pot. RANDOM effects were genotype, replication, genotype $\times$ replication, cycle $\times$ replication, and pot within replication. For microorganism counts, the Shapior-Wilk test for normality (SAS, 2000-2004) indicated that data were not normally distributed. These data were therefore transformed to $\log 10$ for analyses (Zuberer, 1994). Levene's homogeniety of variance $(\mathrm{HoV})$ tests were conducted for each class variable, which indicated heterogeneity in covariance structure of some class variables. Based on those results, the REPEATED/ GROUP option of Proc Mixed (SAS, 2000-2004) was used to specify those structures as appropriate. Least square means, their standard errors, and probabilities of significant differences were calculated using the statement LSMEANS GENOTYPE|CYCLE/DIFF. For ease to the reader, LSMs were back- transformed to decimal numbers when reported in the text and tables.

Sorghum field experiment

The field study was planted at UNL, Lincoln and Ithaca, during 2004 and 2005. Lincoln fields were in soybeansorghum rotations since at least 2000. Prior to the planting of the 2004 field study at Ithaca, the crop sequence was soybean (2000), oats (2001), wheat (2002) then soybean (2003). Prior to planting the Ithaca field in 2005 , it was in 3 years of soybean-sorghum rotation preceded by wheat (2001) and oats (2000). In soybean fields at both locations, glyphosate-resistant soybeans were planted since at least 2000 and glyphosate, a lowpersistence herbicide (Reddy 2001), was applied at the rate of $2.251 \mathrm{ha}^{-1}$. In 2006 at Ithaca, the preemergent herbicide, Canopy ${ }^{\circledR}$, a formulation of chlorimuron ethyl (2-(((((4-chloro-6-methoxypyrimidin-2-yl) amino) carbonyl) amino) sulfonyl) benzoate) and tribenuron methyl (methyl 2-(((4-methoxy-6-methyl-1,3-5-triazin2-yl) methylaminol) carbonyl) amino) sulfonyl) benzoate, also was applied at a rate of $275 \mathrm{~g} \mathrm{ha}^{-1}$ to the soybean crop. For sorghum culture, nitrogen fertilizer was applied prior to planting at both locations, during 2004 through 2007, at $157 \mathrm{~kg} \mathrm{ha}^{-1}$. At Lincoln, $3.36 \mathrm{~kg} \mathrm{ha}^{-1}$ propachlor [2-chloro- $N$ - (1-methylethyl)$\mathrm{N}$-phenylacetamide] and $1.1 \mathrm{~kg} \mathrm{ha}^{-1}$ of atrazine 6-chloro$n$-ethyl- $N$ '-(1-methylethyl)-1,3,5-triazine-2,4,diamine] were applied immediately after planting for weed control. At Ithaca, atrazine was applied at $2.2 \mathrm{~kg} \mathrm{ha}^{-1}$ immediately after planting, followed by an application of quinclorac (3,7-dichloro-8-quinolinecarboxylic acid) at $0.37 \mathrm{~kg} \mathrm{ha}^{-1}$ during 2004 or alachlor (2-chloro-2',6'diethyl-N-(methoxymethyl)acetanilide) at $4.751 \mathrm{ha}^{-1}$ during 2005-2007, and atrazine at $1.1 \mathrm{~kg} \mathrm{ha}^{-1}$, approximately $14 \mathrm{~d}$ post emergence during all 4 years. Chloryrifos (phosphorothioic acid, O,O-diethethyl O$(3,4,5$, trichloro-2-pyridinyl) ester) was applied at Ithaca on June 22, 2004 for grasshopper control.

Immediately before planting, soil was collected as previously described and numbers of culturable fungi and oomycetes, fungi resulting from selection on DCPA, fungi resulting from selection on PCNB, total numbers of culturable bacteria and numbers of fluorescent Pseudomonas spp. per gram of soil were assessed from four approximately one gram samples using dilution plating. The sorghum genotypes Redlan and RTx433 were planted at UNL, Lincoln and Ithaca, in 
three row plots, four replicate plots per location. Plots consisted of three $7.6 \mathrm{~m}$ rows spaced $76 \mathrm{~cm}$ apart. Ithaca was equipped with a center pivot irrigation system and plots received irrigation water. Fields at Lincoln lacked this amenity. Mean monthly temperatures at Lincoln ranged from $20^{\circ}$ to $23^{\circ} \mathrm{C}$ and total rainfall was approx. $33 \mathrm{~cm}$ during the growing season of 2004. During 2005, mean monthly temperatures at Lincoln ranged from $19^{\circ}$ to $26^{\circ} \mathrm{C}$ and approx. $32 \mathrm{~cm}$ of rainfall was received throughout the growing season. At Ithaca, mean monthly temperatures ranged from $19^{\circ}$ to $22^{\circ}$, approx. $40 \mathrm{~cm}$ rainfall was received and supplemental irrigation was applied on August 3, 12, and 19 (2.5 cm per application) during the growing season of 2004. During 2005, the mean monthly temperatures ranged from $17^{\circ}$ to $26^{\circ} \mathrm{C}$, approx. $29 \mathrm{~cm}$ of precipitation was received and irrigation was applied on May 25, June 28, July 5, 11 and 12, and Aug 5 and 23 (3.8 $\mathrm{cm}$ per application).

Two plants, including field soil within the root system, were removed from each three-row plot and brought to the laboratory (Table 1) at approximately 1 month intervals for 4 months (time points). Plants were taken from within the interior of the center row, were non-adjacent, and were surrounded by other plants of the same genotype. Once in the laboratory, the loose soil was removed from the roots by gentle shaking and stored in plastic bags at $4^{\circ} \mathrm{C}$ until processing. Roots were processed immediately and soil was processed within $32 \mathrm{~h}$ of collection. Approximately $1 \mathrm{~cm}$ long pieces were cut from throughout the root system then two approx.1 $\mathrm{g}$ samples were assembled from random pieces. The root samples would have likely included rhizosphere,

Table 1 Culturing and sampling of plants during the field study

\begin{tabular}{|c|c|c|c|c|c|}
\hline & & \multicolumn{2}{|c|}{ Lincoln } & \multicolumn{2}{|c|}{ Ithaca } \\
\hline & & 2004 & 2005 & 2004 & 2005 \\
\hline \multicolumn{2}{|l|}{ Planting date } & $5-27$ & $5-18$ & $5-20$ & $5-23$ \\
\hline \multicolumn{2}{|l|}{ Anthesis (dap) ${ }^{\mathrm{a}}$} & 75 & 71 & 83 & 71 \\
\hline \multirow[t]{4}{*}{ Time points (dap) } & 1 & 28 & 33 & 40 & 39 \\
\hline & 2 & 55 & 62 & 66 & 63 \\
\hline & 3 & 84 & 90 & 98 & 93 \\
\hline & 4 & 123 & 132 & 142 & 131 \\
\hline
\end{tabular}

\footnotetext{
${ }^{a}$ Anthesis was defined as approximately half the anthers were exerted. "dap" indicated "days after planting"
}

rhizoplane and endophytic microorganisms (Compant et al. 2010). For each plant, soil from within the root system, including soil that was gently shaken from roots, was mixed and two $1 \mathrm{~g}$ soil samples were assembled. A dilution series was prepared with each sample and plated onto TSA and $\mathrm{KB}^{+}$agar for bacteria and onto PDA, DCPA and PCNB agar for fungi and oomycetes. Plates were incubated at room temperature (approx. $23^{\circ} \mathrm{C}$ ) and microorganisms were enumerated two to five days following plating. At each time point, single colonies of fluorescent Pseudomonas spp. were transferred from $\mathrm{KB}^{+}$plates to $\mathrm{KB}$ agar and confirmed for fluorescence. At time points 3 and 4 in 2004, and all four time points in 2005, single fungal colonies growing on DCPA and PCNB plates were transferred to one-half strength PDA.

Characterization of fluorescent Pseudomonas spp. and fungi

Collection and confirmation of fluorescent Pseudomonas spp. was as described above (de Souza et al. 2002; Landa et al. 2002; Mazzola et al. 2004; Wang et al. 2001). Putative Pseudomonas isolates were transferred from $\mathrm{KB}^{+}$dilution root and soil suspension plates, and onto KB plates. For many treatments, all fluorescent Pseudomonas isolates on dilution plates were collected. For a few plant samples, there was abundance of isolates and, therefore, up to 12 randomly chosen colonies from countable plates of each treatment were collected. Over 300 root and 400 soil isolates, confirmed for fluorescence, were characterized for extracellular protease and HCN production and for the presence of genes in the phl and phenazine-1-carboxylic acid (PCA) loci. Extracellular protease activity was determined on $2 \%$ skim milk agar (BD). Production of HCN was indicated by a modification of a colorimetric agar plate method (Castric and Castric 1983) as previously described (Funnell-Harris et al. 2008). To detect the presence of phl, PCR amplification of phlD was conducted (Bangera and Thomashow 1999) while the presence of $P C A$ was detected using primer sequences from within the $p h z C$ and $p h z D$ genes (Mavrodi et al. 1998; Raaijmakers et al. 1997). DNAs from individual bacterial isolates were prepared and diluted as previously described (Mazzola and Gu 2002). Amplifications were conducted using primers $\mathrm{Phl} 2 \mathrm{a}$ and Phl2b for phl and PCA2a and PCA3b for PCA 
(Raaijmakers et al. 1997). Reactions were $25 \mu \mathrm{l}$ volumes including $1.5 \mathrm{mM} \mathrm{MgCl} 2$ and 2.0 to 2.5 Units of Amplitaq Gold [Applied Biosystems (AB), Foster City, CA USA] (Mazzola et al. 2004; Raaijmakers et al. 1997). Amplifications were conducted on a Gene Amp ${ }^{\circledR}$ PCR System 9700 (AB). Conditions for amplifying phl (Funnell-Harris et al. 2008) and PCA (Raaijmakers et al. 1997) were as previously reported. DNA templates extracted from isolates Q2-87 and 2-79 served as positive controls for $p h l$ and $P C A$, respectively (Bangera and Thomashow 1999; Mavrodi et al. 1998). Amplification products were size-fractionated by electrophoresis on $1 \%$ agarose gels, then visualized by treatment with ethidium bromide solution (Bio-Rad, Laboratories, Inc., Hercules, CA).

Five to twenty fungal isolates were chosen at random from each set of DCPA and PCNB media plates from time points 3 and 4 at both locations during 2004 and all time-points at both locations during 2005. Isolates were transferred to one-half-strength PDA and identified morphologically as previously described (Funnell and Pedersen 2006). Fungi similar to Alternaria spp. were transferred to $2 \%$ water agar by point inoculation; conidiophores and conidia were induced to form by placing approximately $1 \mathrm{~cm}^{2}$ sterilized filter paper (Whatman \#1, Whatman International Ltd., Maidstone, England) over the inoculation site. Likewise, to observe formation of conidiophores and conidia of putative Fusarium spp., agar blocks from PDA cultures were transferred to $1.5 \%$ agar containing $80 \mathrm{mM}$ potassium chloride. On the basis of colony morphologies and morphologies of conidiophores and conidia, fungi were identified as Alternaria spp., members of Gibberella fujikuroi species complex, other Fusarium spp., or other fungi. Species in $G$. fujikuroi that commonly infect sorghum include Fusarium thapsinum Klittich, Leslie, Nelson et Marasas sp. nov., Fusarium verticillioides (Sacc.) Nirenberg ( $=F$. moniliforme), Fusarium proliferatum (Matsush.) Nirenberg ex Gerlach \& Nirenberg and Fusarium subglutinans (Wollenw. \& Reinking) P.E. Nelson, Toussoun \& Marasas (Nelson et al. 1983).

\section{Statistical analyses}

The field study was analyzed as two experiments, one conducted at Lincoln and one at Ithaca, using the PROC MIXED procedure of SAS (SAS 2000-2004). Time point
(1, 2, 3, 4), genotype (Redlan, RTx433), and their interaction were considered fixed effects in the MODEL. Each experiment was a $4 \times 2$ factorial conducted in a randomized complete block with four replications in each of 2 years (2004 and 2005). Within each replication, dependent variable response was measured on two individual plants and associated soil. CLASS variables were therefore year, replication, genotype, time point, and plant. RANDOM effects were year, replication (year), replication $\times$ genotype, replication $\times$ time point, and plant (replication). The Shapior-Wilk test for normality (SAS 2000-2004) indicated that data were not normally distributed. Data were therefore transformed to $\log 10$ for analyses (Zuberer 1994). Levene's homogeniety of variance $(\mathrm{HoV})$ tests were conducted for each class variable, which indicated heterogeneity in covariance structure of some class variables. Based on those results, the REPEATED/GROUP option of Proc Mixed (SAS 2000-2004) was used to specify those structures as appropriate. Because of relatively small sample size, the Kenward-Roger (KR) option was specified for degrees of freedom for these experiments. Least square means, their standard errors, and probabilities of significant differences were calculated using the statement LSMEANS GENOTYPE|TIMEPOINT/DIFF. For ease to the reader, LSMs were back-transformed to decimal numbers when reported in the text and tables.

\section{Results}

Mean seedling weights and numbers of microorganisms during cycling of wheat and sorghum seedlings.

Seedling weights In general, mean total fresh weight (g) of stalks and leaves of wheat and sorghum seedlings increased after cycle 1 but stabilized or somewhat declined in cycle 4 (Fig. 1). For Lincoln soil (Fig. 1a), mean weights of seedlings were significantly different for plant genotype $(P=0.02)$, cycle $(P=0.03)$ and genotype $\times$ cycle interactions $(P<0.01)$. Effects of genotype $\times$ cycle interactions were significant $(P=0.01)$ for mean weights of plants cycled in Ithaca soil (Fig. 1b).

Weights of roots with rhizosphere soil for cycle 1 also were analyzed; effects of soil were significant $(P=0.05)$. Weights from seedlings grown in Lincoln soil were significantly different $(P<0.01)$ for Lewjain (0.36 $\mathrm{g} \pm 0.04)$ versus either Redlan $(0.53 \mathrm{~g} \pm 0.5)$ or 


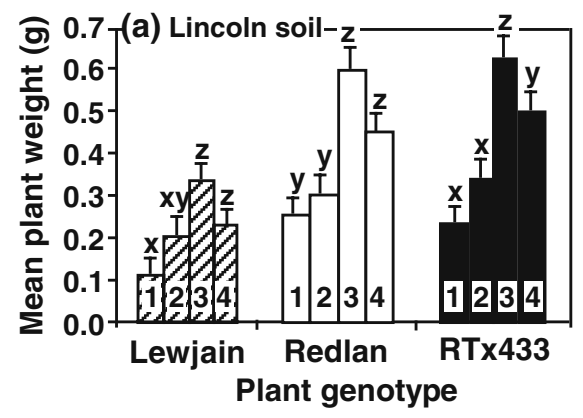

Fig. 1 Mean total wet weights (g) of stalks and leaves of seedlings of wheat cultivar Lewjain and sorghum genotypes Redlan and RTx433 after each of four 4-week cycles. For cycle 1 , plants were grown in pots containing soil obtained from sorghum fields at Lincoln or Ithaca, NE. Stalk and leaves from each plant were weighed immediately at harvest at the end of

RTx433 (0.50 g \pm 0.04$)$. These differences were not apparent between seedling genotypes grown in Ithaca soil (mean seedling weight $0.69 \mathrm{~g} \pm 0.04 ; P \geq 0.35$ ).

Numbers of fluorescent Pseudomonas spp. associated with roots and soil Numbers of fluorescent Pseudomonas spp. in Lincoln soil (cfu per gram) prior to planting were not significantly different from those after cycle 1 (Fig. 2a; preplant $\mathrm{cfu} \mathrm{g}^{-1}$ soil is indicated by asterisk on left side of histogram). However, mean

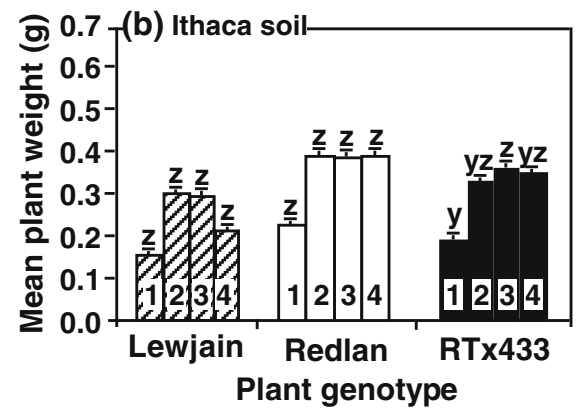

the cycle. For cycles 2, 3 and 4, seeds were sown into cycled soil. The experiment was conducted twice in each soil. Numbers on bars indicate cycles. Positive SEs are shown. Within each genotype, bars with differing letters were significantly different at $P \leq 0.05$

number of Pseudomonas spp. obtained from Ithaca soil prior to planting was significantly greater $(P<0.01)$ than those following planting of Lewjain or RTx433 seedlings (Fig. 2b).

Effects of genotype $\times$ cycle interactions were significant for mean numbers of fluorescent Pseudomonas spp. on roots or in soil throughout cycling (Table 2). By cycle 4, numbers of isolates in both soils were greater when planted with Redlan than with Lewjain (from approx. five to ten fold greater). Numbers of soil
Fig. 2 Mean numbers of fluorescent Pseudomonas spp. (log) per gram of (a), (b) soil or (c), (d) roots during cycling of wheat cultivar Lewjain and sorghum genotypes Redlan and RTx433. Cycling was conducted in soil obtained from sorghum fields at (a), (c) Lincoln or (b), (d) Ithaca, NE. Two experiments were conducted with each soil. Positive SEs are shown. Comparisons were made between plant genotypes within each cycle. Bars with differing letters were significantly different at $\mathrm{P} \leq 0.05$
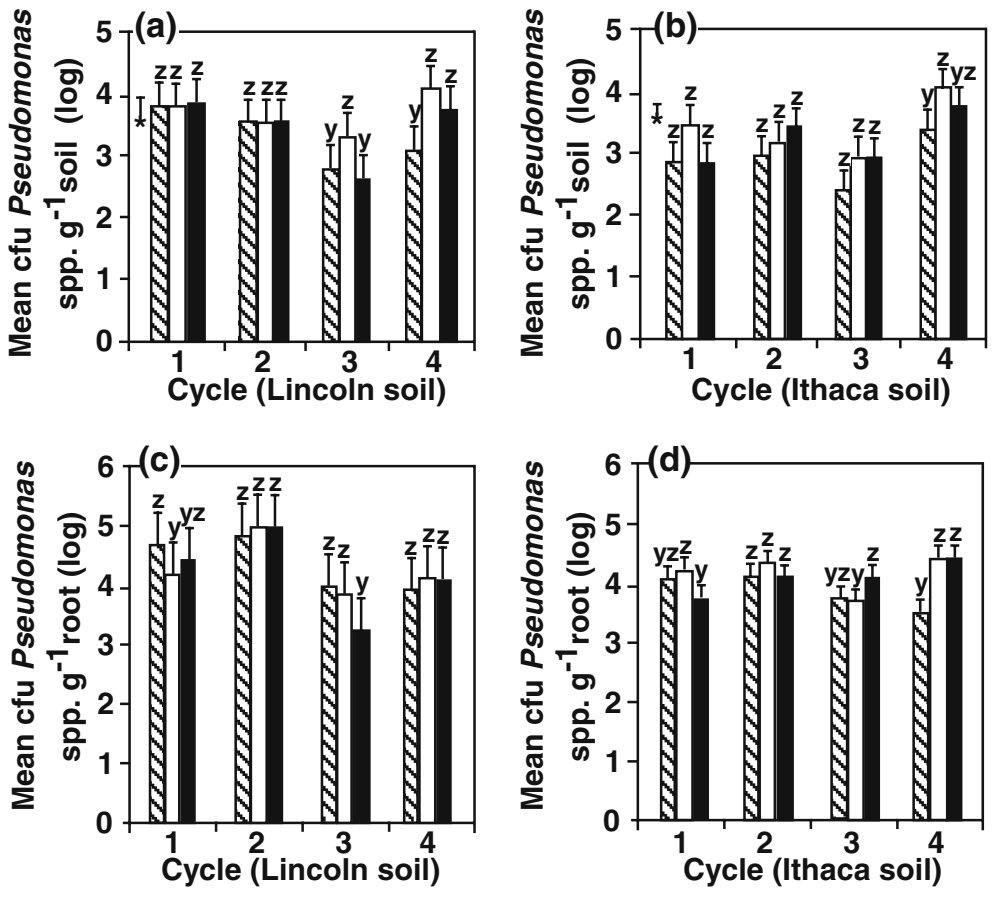

Plant genotypes: $\square$ Lewjain

$\square$ Redlan $\square$ RTx433 
Table 2 Analyses of variances (ANOVAs) for main effects and their interaction for microorganisms associated with roots and soil of wheat cultivar Lewjain and sorghum genotypes Redlan and RTx433, grown in soil from two sorghum fields (Lincoln and Ithaca, NE) ${ }^{\mathrm{a}}$

\begin{tabular}{|c|c|c|c|}
\hline \multirow[t]{2}{*}{ Effects } & \multicolumn{3}{|c|}{ Medium $^{\mathrm{b}}$} \\
\hline & $\mathrm{KB}$ & TSA & PDA \\
\hline \multicolumn{4}{|l|}{ Soil $^{\mathrm{c}}$} \\
\hline \multicolumn{4}{|l|}{ Lincoln } \\
\hline Genotype & 0.17 & 0.11 & 0.29 \\
\hline Cycle & 0.48 & $<0.01$ & 0.05 \\
\hline Genotype $\times$ Cycle & $<0.01$ & 0.23 & 0.01 \\
\hline \multicolumn{4}{|l|}{ Ithaca } \\
\hline Genotype & 0.40 & 0.45 & 0.66 \\
\hline Cycle & 0.16 & 0.58 & 0.84 \\
\hline Genotype $\times$ Cycle & 0.01 & $<0.01$ & $<0.01$ \\
\hline \multicolumn{4}{|l|}{$\operatorname{Roots}^{\mathrm{d}}$} \\
\hline \multicolumn{4}{|l|}{ Lincoln } \\
\hline Genotype & 0.36 & & \\
\hline Cycle & 0.45 & & \\
\hline Genotype $\times$ Cycle & $<0.01$ & & \\
\hline \multicolumn{4}{|l|}{ Ithaca } \\
\hline Genotype & 0.39 & & \\
\hline Cycle & 0.64 & & \\
\hline Genotype $\times$ Cycle & $<0.01$ & & \\
\hline
\end{tabular}

${ }^{a}$ Differences of Least Squares Means (LSM) considered significant at $P \leq 0.05$

${ }^{\mathrm{b}} \mathrm{KB}$ indicates King's B agar with amendments, semi-selective for fluorescent Pseudomonas spp. TSA indicates one-tenth strength tryptic soy agar with amendments to estimate total culturable aerobic bacteria. PDA indicates one-fifth potato dextrose agar with amendments, used to estimate total culturable fungi and oomycetes. Soil suspensions were screened on KB, TSA and PDA while root suspensions were only screened on KB

${ }^{\mathrm{c}}$ Two soil samples per plant were suspended in sterile distilled water and dilutions were prepared. Dilutions were spread onto $\mathrm{KB}$, TSA and PDA agar media

${ }^{\mathrm{d}}$ One suspension of root pieces was prepared and diluted. Three aliquots of each dilution were spread onto KB agar medium

isolates were similar between the three plants until the third (Lincoln) or fourth (Lincoln and Ithaca) cycle (Fig. 2a, b). Ithaca soil planted with RTx433 seedlings resulted in a significant increase in numbers of fluorescent Pseudomonas spp. both on roots and in soil $(P=0.01)$ (Fig. 2b, d) but on Lewjain roots, numbers declined significantly $(P=0.02)$ (Fig. 2d). Significant increases or decreases in numbers of Pseudomonas spp. were not observed when cycling was conducted in Lincoln soil. These results suggest differences in root and soil colonization by fluorescent Pseudomonas spp. attributable to sorghum genotype or plant species, but also an influence of soil characteristics.

Total culturable bacteria and fungi and oomycetes in soil When numbers of microorganisms in Lincoln soil were compared prior to planting and after cycle 1 , there were essentially no changes. In Ithaca soil, changes in numbers of culturable fungi and oomycetes declined for all three genotypes from approx. $1.38 \times 10^{5} \mathrm{cfu}$ per gram soil prior to planting to as low as $3.24 \times 10^{4} \mathrm{cfu}$ per gram soil after planting of Redlan $(P<0.01)$. There were no changes in numbers of culturable bacteria in Ithaca soil.

During cycling, effects of cycle were significant for numbers of culturable bacteria per gram of Lincoln soil (Table 2); mean numbers of total soil bacteria were significantly greater for Lewjain than for Redlan seedlings during cycles 2,3 and 4 ( $P \leq$ 0.03 ) (Table 3; cycle 4 is shown). Effects of genotype $\times$ cycle interactions also were significant for numbers of culturable bacteria in Ithaca soil, but there were fewer cfu per gram in Lewjain soil than in soil associated with Redlan (cycle 3) or with both sorghum genotypes (cycle 4) (Table 3).

Mean numbers of culturable fungi and oomycetes per gram of soil were significantly effected by cycle (Lincoln) and genotype $\times$ cycle interactions (Lincoln and Ithaca) (Table 2). In Lincoln soil, numbers of fungi and oomycetes increased from cycle 1 to cycle 4 for each plant genotype $(P \leq 0.04)$ and at cycle 4 , Lewjain soil had significantly greater mean numbers of fungi and oomycetes than either sorghum genotype (Table 3). Results from seedlings planted in Ithaca soil were similar, but were not significantly different $(P \geq 0.06)$.

Numbers and characteristics of microorganisms associated with two sorghum genotypes grown at two locations for 2 years

Numbers of fluorescent Pseudomonas spp. associated with roots and soil In general, there appeared to be a greater effect of genotype on numbers of Pseudomonas spp. in rhizospheres than in plot soils. For roots, effect of location $\times$ genotype interactions was significant $(P=$ 
Table 3 Mean numbers of culturable bacterial or fungal and oomycete cfu per gram of soil after cycle 4 of cycling seedlings of wheat cultivar Lewjain and sorghum genotypes Redlan and RTx433 in soils from two sorghum fields from Lincoln or Ithaca, NE

\begin{tabular}{|c|c|c|c|c|}
\hline \multirow[t]{2}{*}{ Plant genotype } & \multicolumn{2}{|c|}{ Bacteria $\left(\mathrm{cfu} \mathrm{g}^{-1}\right)^{\mathrm{a}}$} & \multicolumn{2}{|c|}{ Fungi and oomycetes $\left(\mathrm{cfu} \mathrm{g}^{-1}\right)^{\mathrm{b}}$} \\
\hline & Lincoln & Ithaca & Lincoln & Ithaca \\
\hline Lewjain & $3.72 \times 10^{7} z^{c}$ & $1.26 \times 10^{7} \mathrm{y}$ & $6.76 \times 10^{5} \mathrm{z}$ & $9.77 \times 10^{4} \mathrm{z}$ \\
\hline Redlan & $2.45 \times 10^{7} y$ & $3.47 \times 10^{7} \mathrm{z}$ & $2.59 \times 10^{5} \mathrm{y}$ & $3.47 \times 10^{4} \mathrm{z}$ \\
\hline RTx433 & $2.95 \times 10^{7} \mathrm{zy}$ & $5.37 \times 10^{7} \mathrm{z}$ & $3.31 \times 10^{5} \mathrm{y}$ & $5.89 \times 10^{4} \mathrm{z}$ \\
\hline
\end{tabular}

${ }^{a}$ Mean numbers of culturable bacteria per $\mathrm{g}$ soil as determined by dilution plating of soil suspensions onto one-tenth strength tryptic soy agar (TSA)

${ }^{b}$ Mean numbers of culturable fungal and oomycete cfu per g soil as determined by dilution plating onto one-fifth strength potato dextrose agar (PDA) amended with $0.04 \%$ Triton X-100 and $50 \mathrm{mg} / \mathrm{l}$ ampicillin

${ }^{\mathrm{c}}$ Comparisons were made between each plant genotype for a given soil and microorganism. Numbers with the same letters indicate lack of significant difference

0.02). For plants grown at Lincoln, $\mathrm{RT} x 433$ roots tended to have greater numbers of pseudomonads prior to anthesis than Redlan roots (Fig. 3a: time point $1, P=$ 0.06 ; time point $2, P=0.01$ ), while plants of both genotypes after flowering had similar numbers of pseudomonads $(P \geq 0.73)$. For plants grown at Ithaca, there were no significant differences in numbers of Pseudomonas spp. across time points (Fig. 3b). Mean numbers of pseudomonads in soils from pre-planting numbers through numbers sampled through the growing season were not significantly different for main effects or their interactions $(P \geq 0.10)$.

\section{Characteristics of fluorescent Pseudomonas spp. associated with roots and soil Percentages of root}

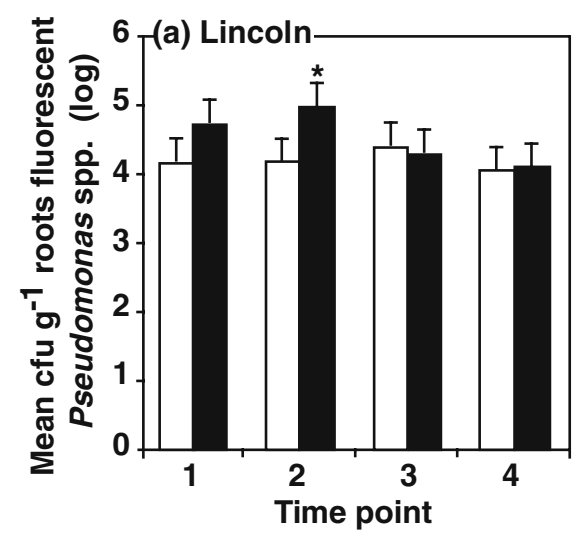

Plant genotypes:

Fig. 3 Mean numbers of fluorescent Pseudomonas spp. (log) per gram of roots of sorghum genotypes grown at Lincoln (a) or Ithaca (b), NE for 2 years. Plots at Ithaca were irrigated while those at Lincoln were not. Samples were taken at approx. and soil fluorescent Pseudomonas spp. with each of four biological control characteristics are shown in Table 4. Location effects for HCN-producing root isolates were demonstrated $(P=0.02)$; percent of $\mathrm{HCN}$-producers from plants grown at Ithaca were significantly greater than those from plants grown at Lincoln. There was a significant decline in numbers of $\mathrm{HCN}$-producing pseudomonads isolated from Redlan roots at Ithaca (Table 4; $P=0.05$ ) while this decrease in $\mathrm{HCN}$-producers among Redlan root isolates was not apparent from plants grown at Lincoln. There were no changes in numbers of $\mathrm{HCN}$-producing isolates from RTx433 roots from plants grown at either location. Mean percents of HCN-producing soil isolates associated with cv. Redlan plants grown at Lincoln increased through the

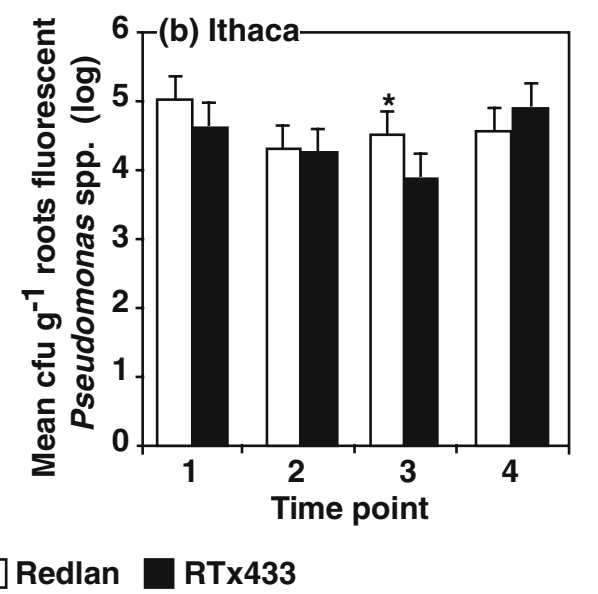

1 month intervals throughout the growing season (see Table 1 for exact dates). An asterisk indicates that within a given time point, mean was significantly greater 
Table 4 Characterization of fluorescent Pseudomonas isolates obtained from roots and soil from field plots of sorghum genotypes Redlan and RTx433 planted at two locations

\begin{tabular}{|c|c|c|c|c|c|c|c|c|c|}
\hline \multirow[t]{3}{*}{ Plant genotype } & \multirow[t]{3}{*}{ Time point } & \multicolumn{8}{|c|}{ Percent of isolates with trait or genotype ${ }^{a}$} \\
\hline & & \multicolumn{2}{|l|}{$\mathrm{HCN}$} & \multicolumn{2}{|c|}{ Protease } & \multicolumn{2}{|l|}{$p h l$} & \multicolumn{2}{|l|}{$P C A$} \\
\hline & & Roots & Soil & Roots & Soil & Roots & Soil & Roots & Soil \\
\hline \multicolumn{10}{|c|}{ Location-Lincoln } \\
\hline \multirow[t]{4}{*}{ Redlan } & 1 & 0 & 0 & 36 & 7 & 0 & 0 & 0 & 0 \\
\hline & 2 & 6 & 10 & 39 & 58 & 0 & 0 & 0 & 0 \\
\hline & 3 & 0 & 5 & 63 & 63 & 0 & 0 & 0 & 0 \\
\hline & 4 & 13 & 25 & 13 & 60 & 0 & 0 & 0 & 0 \\
\hline \multirow[t]{4}{*}{$\mathrm{RTx} 433$} & 1 & 0 & 3 & 47 & 32 & 0 & 0 & 0 & 0 \\
\hline & 2 & 5 & 19 & 58 & 29 & 4 & 3 & 0 & 0 \\
\hline & 3 & 0 & 3 & 67 & 74 & 0 & 6 & 0 & 0 \\
\hline & 4 & 8 & 5 & 45 & 40 & 0 & 0 & 0 & 0 \\
\hline \multicolumn{10}{|l|}{ Location-Ithaca } \\
\hline \multirow[t]{4}{*}{ Redlan } & 1 & 45 & 15 & 44 & 30 & 4 & 10 & 0 & 5 \\
\hline & 2 & 30 & 0 & 58 & 9 & 0 & 0 & 0 & 0 \\
\hline & 3 & 12 & 7 & 46 & 22 & 0 & 3 & 0 & 0 \\
\hline & 4 & 9 & 5 & 64 & 19 & 0 & 0 & 0 & 6 \\
\hline \multirow[t]{4}{*}{ RTx433 } & 1 & 20 & 18 & 68 & 35 & 7 & 2 & 0 & 0 \\
\hline & 2 & 30 & 14 & 32 & 33 & 0 & 3 & 0 & 0 \\
\hline & 3 & 9 & 7 & 21 & 9 & 0 & 2 & 0 & 0 \\
\hline & 4 & 13 & 12 & 38 & 25 & 5 & 0 & 0 & 0 \\
\hline
\end{tabular}

${ }^{a} \mathrm{HCN}$ indicates production of hydrogen cyanide. Protease indicates production of extracellular protease. $p h l$ and $P C A$ indicate presence of genes involved in production of 2,4-DAPG and phenazine-1-carboxylic acid, respectively. Standard errors (SE) for HCNproducing root and soil isolates were 12 and 9, respectively. SEs for protease-producing root and soil isolates were 25 and 23 , respectively. SEs for root and soil isolates with $p h l$ were 2 and 3, respectively. SEs for soil isolates with $P C A$ were 2 . Since no $P C A^{+}$ root isolates were detected, SEs were not calculable

growing season (Table $4 ; P=0.07$ ). The total percent of soil isolates with extracellular protease activity obtained from Lincoln plots $(45.2 \pm 14 \%)$ was significantly greater than those from Ithaca $(22.6 \pm 14.0 \% ; P=0.02)$.

Percentages of fluorescent Pseudomonas spp. with phl declined in soil isolates associated with Redlan plants grown at Ithaca $(P=0.02)$ (Table 4). There were no $p h l$ isolates detected from Redlan plots at Lincoln while $p h l$ isolates were detectable from roots and soil of RTx433 plants at both locations. $P C A$ was detected only in soil isolates collected from Redlan plots at Ithaca.

Numbers of total bacteria and numbers of fungi and oomycetes from roots and soil of field-grown plants as determined by culturing on three media There were no significant effects or interactions for mean numbers of total bacteria associated with roots or soil of RTx433 or Redlan prior to planting and throughout the growing season.

Culturable fungi and oomycetes were enumerated on PDA medium and on two media semi-selective for Alternaria (DCPA) and Fusarium (DCPA and PCNB). Effect of medium was significant $(P<0.01)$. For root isolates, there were significant location $\times$ time point effects for all three media $(P \leq 0.01)$. Mean total numbers of root fungi and oomycetes (cfu per gram) declined when plants were grown at Lincoln, from $3.31 \times 10^{5}$ to $5.89 \times 10^{4}$ for Redlan $(P=0.01)$ and from 
$2.82 \times 10^{5}$ to $7.08 \times 10^{4}$ for RTx433 plants $(P=0.05)$, while they stayed virtually the same, approx. $1 \times 10^{5}$, throughout the growing season at Ithaca $(P \geq 0.27)$. For mean numbers of root fungi recovered on DCPA, there were significant increases on plants grown at Ithaca [from $4.37 \times 10^{4}$ to $1.00 \times 10^{5} \mathrm{cfu}$ per gram for Redlan $(P=0.04)$ and from $7.94 \times 10^{4}$ to $1.86 \times 10^{5}$ cfu per gram for RTx433 $(P=0.03)]$ but not on roots of plants grown at Lincoln. For mean numbers of isolates obtained by selecting on PCNB plates, location $\times$ time point $(P<$ $0.01)$ and location $\times$ time point $\times$ genotype $(P=0.03)$ effects were significant; there appeared to be a decline of mean cfu per gram of roots from RTx433 plants grown at Lincoln (from $6.31 \times 10^{4}$ to $1.58 \times 10^{4}$ ) but an increase from plants grown at Ithaca (from $1.23 \times 10^{4}$ to $\left.4.07 \times 10^{4}\right)$.

Fungal colonies were sub-sampled from DCPA and PCNB plates from time points 3 and 4 from both locations and identified as Alternaria spp., Fusarium spp. in the $G$. fujikuroi species complex, other Fusarium spp., or other fungi. There was significant difference in percentages of G. fujikuroi isolates from roots of Redlan plants $(8.6 \%)$ and RTx433 (3.0\%) $(\mathrm{SE}=3.3 ; P=0.05)$, while there were no significant differences in mean percent of this fungal group in soil (RTx433, 6.8\%; Redlan, 12.8\%; $\mathrm{SE}=5.0$; $P=0.18$ ). There were no significant differences between the genotypes for percentages of Alternaria spp., other Fusarium spp, or other fungi.

Changes in percentages of isolates within each fungal group were assessed for 2005. The greatest changes occurred from the first (vegetative) through the third time points (after anthesis; see Table 1) and for some fungal groups, were different for the two sorghum genotypes. Significant increases in percent of Alternaria spp. isolated from roots (from 0 to $10 \% ; \mathrm{SE}=2.5)$ and significant decreases in percents of soil Alternaria spp. (from 5 to $0 \%$; $\mathrm{SE}=$ 2.5) were observed for Redlan plants $(P=0.01)$; no Alternaria isolates were obtained in root or soil subsamples from RTx433 plants. Decreased percentages of G. fujikuroi isolates to undetectable at the third time point were observed in soil (from $27.5 \pm 10.3 \%$ at time point $1 ; P<0.01$ ) of RTx433 plants while percents of fungi other than Fusarium or Alternaria spp. increased significantly for RTx433 plot soil (from 27.5 to $65.0 \% ; \mathrm{SE}=16.3 ; P=0.04$ ). From the third to the fourth time points, percents of root and soil isolates that were G. fujikuroi or other Fusarium spp. stayed approx. the same or increased for both sorghum genotypes, but not significantly so $(P \geq$ $0.19)$.

\section{Discussion}

Sorghum production often occurs in rotation cropping systems and less so in monoculture (Dhuyvetter et al. 1996; Doggett 1988). This is in contrast to wellstudied grasses such as wheat or flax, which have been grown in monoculture, in some cases, for considerable duration (Landa et al. 2006). In the case of sorghum, it is of interest whether some genotypes induce growth of potentially beneficial or pathogenic microorganisms during periods within the growing season or under environmental stresses in which the plant would be particularly vulnerable (Gaudet and Major 1986; Pratt and Janke 1980). In this way, it is conceivable to ameliorate or prevent seedling or root and crown diseases, or perhaps systemic infection of grain, by selection of genotype (Idris et al. 2007; Murillo-Williams and Munkvold 2008; Raju et al. 1999). We tested the hypothesis that sorghum genotype influences the numbers and characteristics of root- and soil-associated fungi and bacteria. We discovered that the two sorghum genotypes used in this study can differentially affect populations and their composition, but soil environment often has strong effects on soil microorganism populations.

In growth chamber assays, numbers of fluorescent Pseudomonas spp. in cycled soil planted with seedlings of sorghum cultivar Redlan were significantly greater than for wheat in cycles 3 or 4 for both soils (Fig. 2a, b). In root samples, numbers of Pseudomonas spp. increased significantly during cycling of sorghum genotype RTx433 but declined significantly on wheat when seedlings were planted in Ithaca soil; no significant changes were observed in Lincoln soil. Because conditions for all experiments were similar, changes in soil microorganisms appear to be independent of soil type while changes in root populations may be affected by a combination of plant genotype and soil type. Mazzola et al. (2004) observed that numbers of fluorescent Pseudomonas spp. in rhizospheres of wheat cycled in apple orchard soils were influenced by soil properties but trends in population structure appeared to be dependent on the wheat cultivar and independent of soil type. In the present 
study, it might be argued that changes in numbers of fluorescent Pseudomonas spp. on roots of Lewjain seedlings declined similarly in both soils, but changes in pseudomonad populations on roots of sorghum genotypes grown in different soils did not follow a clear trend (Fig. 2c, d). Therefore, the ability of a plant to influence root and soil microbial populations despite soil-type may be a characteristic of some, but not all, plant species. In an investigation of rhizosphere metabolite production and enzymatic activity from six plant species grown in four different soils, Bachman and Kinzel (1992) found that these processes in some plant species (Medicago sativus, Raphanus sativus and Amaranthus lividus) were relatively consistent across soils; however, two of the soils appeared to negatively affect one or more processes across all plant species studied. While investigating fluorescent Pseudomonas spp. on flax (Linum usitatissimum (L.)), Latour and associates found that soil influenced composition of rhizosphere populations (Latour et al. 1996) and root colonization by introduced pseudomonads (Latour et al. 1999).

Redlan and RTx433 seedlings may differentially influence the numbers of culturable microorganisms in rhizospheres and soil. Effect of genotype $\times$ cycle interactions were significant for plant wet weight (Fig. 1) and for nearly all microorganism counts $(P \leq$ 0.01) except for total Lincoln soil bacteria, while effect of cycle was not significant for most measurements. This suggests that plant genotype may have had an influence on response in each cycle. Increasing organic matter, in the form of decaying roots, may have affected plant fresh weight and numbers of root and soil microorganisms through cycling (Meharg et al. 1998; Semenov et al. 1999). Roots were left in pot-soil, as commonly done in cycling experiments, to increase numbers of rhizosphere microorganisms (Mazzola et al. 1992; Meharg et al. 1998). Influence of plant genotype may have been simply differences in root biomass between the three plants, or may have been more subtle differences in root architecture or physiology. It was previously shown that 5-day-old seedlings of sorghum cv. Redlan produced relatively large amounts of sorgoleone while genotype RTx433 produced the lowest amount of 25 accessions tested (Nimbal et al. 1996). This allelopathic compound, when exogenously applied to native soil, was detectable at 4 weeks following application (Czarnota et al. 2001); thus there was one known biochemical difference between roots of Redlan and RTx433 seedlings.

In the field study, genotype also may influence culturable root microorganism populations. When monitored throughout the growing season, effect of genotype $\times$ location interactions were significant for numbers of fluorescent Pseudomonas spp. and location $\times$ genotype $\times$ time point interactions were significant for numbers of fungi recovered on PCNB medium, semi-selective for Fusarium spp. That sorghum genotype may influence population numbers in these two groups, by interacting with environment or plant age, is important because these bacterial and fungal genera include species potentially beneficial (Das et al. 2008; Venne et al. 2009) or pathogenic (Leslie et al. 2005; Muriithi and Claflin 1997) to sorghum. At Lincoln, numbers of root-associated fluorescent Pseudomonas spp. were greater on RTx433 plants prior to anthesis (time points 1 and 2; Fig. 3) while numbers of pseudomonads were significantly greater on Redlan roots at time point 3, just after anthesis, on plants grown at Ithaca. Effect of genotype $\times$ location interactions were not significant for numbers of soil microorganisms associated with each genotype. In a previous study focusing on colonization of wheat and maize roots from flowering through harvest, when $P$. fluorescens strain CHA0-Rif was applied to wheat, rhizosphere populations declined after flowering, but applications to maize resulted in low colonization but then increased at grain maturation through post-harvest (Troxler et al. 1997); under certain conditions of environment and soil type, plant physiological stage plays a role in root colonization by microorganisms (Berg and Smalla 2009; Hodge et al. 2009).

Significant differences in prevalence of different microbial groups on culture medium can indicate differences in response to plant genotypes (Larkin et al. 1993). However, if the prevalence of different microbial groups is not significantly different on different plants, then prevalence of specific genotypes within a microbial group can be significantly different than microbial genotypes found on another plant (e. g. microbial diversity) (Garbeva et al. 2008). Cultureindependent methods that use DNAs extracted from environmental samples then analyzed for genotypic differences include denaturing gradient gel electrophoresis, quantitative PCR, most probable number 
PCR and metagenomics (Bergsma-Vlami et al. 2005; Garbeva et al. 2008; Picard et al. 2008; Sanguin et al. 2009; Sørensen et al. 2009; Svercel et al. 2009; Zhang and $\mathrm{Xu} 2008)$.

In the present study, it was desired to obtain cultures of sorghum isolates specific for each line for future research in the interaction of sorghum with fluorescent Pseudomonas spp., therefore we chose cultural methods of enumerating microorganisms followed by assessment of each isolate for four traits that may contribute to biological control capabilities as an indication of diversity. When characterizing isolates for production of $\mathrm{HCN}$, location effects were observed for $\mathrm{HCN}$ production by root-associated isolates and protease production by soil isolates. $\mathrm{HCN}$ production has been implicated in biological control but also can have negative effects on plants (Flores-Vargas and O'Hara 2006; Rezzonico et al. 2007). Differences in biotic and abiotic factors may affect expression of biocontrol traits, thus, whether $\mathrm{HCN}$ or protease production occurred in environments described in the present study may have affected the success of colonization by fluorescent Pseudomonas spp. carrying these traits at different times in the growing season (Duffy et al. 2004). phl isolates were identified from roots and plot soil from RTx433 plants at Lincoln and from plants of both genotypes at Ithaca. There possibly may have been a genotype $(P=0.13)$ or genotype $\times$ location $(P=0.19)$ effect on percent of pseudomonads with $p h l$ on roots or in soil, respectively ( $P \geq 0.39$ for location effects). $P C A$, which does not have a cosmopolitan distribution as phl (Raaijmakers et al. 1997), also was found in Ithaca soil planted with Redlan. It appears that a combination of sorghum genotype, soil and environmental factors may be influencing the composition of fluorescent Pseudomonas populations (Doran et al. 1998; Mazzola and Gu 2000).

Fusarium spp. within the G. fujikuroi species complex (formerly known as $F$. moniliforme) includes several pathogens of sorghum (Leslie et al. 2005). Species within this complex, $F$. thapsinum, F. verticillioides or $F$. proliferatum can cause seedling diseases and stalk rots (Huang and Backhouse, 2005; Leslie et al. 2005; Petrovic et al. 2009) or infect asymptomatically and may result in systemic infection of grain (Leslie et al. 1992; MurilloWilliams and Munkvold 2008). Alternaria spp. are also commonly isolated from sorghum grain (Funnell and Pedersen 2006). Fusarium stalk rots can cause lodging and reduce yield (Tesso et al. 2005) while grain infections by Alternaria spp. and G. fujikuroi can reduce quality and perhaps result in toxincontaminated grain (Audilakshmi et al. 2007; Leslie et al. 2005; Murillo-Williams and Munkvold 2008). Thus, prevalence of these fungi on sorghum roots and in field soil is of great interest. In the present study, sorghum genotype also influenced fungal population structure in rhizospheres. Culturable fungi and oomycetes associated with roots and soil were screened using three media with different selectivity. One-fifth strength PDA with amendments allowed confined growth of fungal and oomycete colonies and prevented bacterial growth. DCPA and PCNB were semi-selective for Alternaria (DCPA) and Fusarium spp. (DCPA and PCNB). Identification of G. fujikuroi isolates from DCPA and PCNB showed that the mean percentages were significantly greater on Redlan roots than on RTx433 roots. At the roots, a balance of pathogens with beneficial microorganisms, including those producing compounds antagonistic to fungi, may prevent infection (Dubuis et al. 2007; Picard and Bosco 2008).

Cultural techniques for enumerating microorganisms allowed for organisms of interest to be in-hand for future investigations. But, culture media only provided snippets of information of actual microorganism populations in the soil, or associated with roots. Each medium is a new environment for root- or soil-associated populations which benefits some microorganisms and challenges others (Dunbar et al. 1997). Thus, use of media for enumeration of microorganisms provided a relative basis of comparison since only culturable microorganisms were examined. Comparisons between DCPA and PCNB, originally formulated to select for Fusarium spp. (Andrews and Pitt 1986; Nash and Snyder 1962), could be made in this study since fungi from each suspension were selected on both. For numbers of fungal colonies growing on each medium, there were no significant differences with regard to location when considering root $(P \geq 0.43)$ or soil $(P \geq 0.62)$ suspensions. Approximately $38 \%$ of colonies sub-cultured from DCPA or $62 \%$ of the sub-cultured colonies from PCNB were Fusarium spp. (numbers were similar for root and soil suspensions). In a study testing several semi-selective media, Bragulat et al. (2004) selected fungi from suspensions of contaminated grain and feed samples 
and found that approximately $18 \%$ of colonies were Fusarium spp. on either DCPA or PCNB. In the current study, higher percentages of Fusarium spp. obtained from these media may have been due to the type of natural samples (roots or soil) or to the subsampling process.

The two studies described in this work utilized sorghum genotypes with different levels of sorgoleone production, planted in two different soils and assessed for soil and root microorganisms associated with each genotype. The results, taken together, provide evidence that sorghum genotype contributes to determining the composition of microorganism populations. But they also indicate that plant age, soil and environment are involved in this process, an exciting but challenging conclusion for further research. During seedling cycling, there were similar effects in the two modestly different soils on fluorescent Pseudomonas spp. numbers during later cycles. However, during the field study, the effects of plant genotype on fluorescent Pseudomonas numbers were evident throughout the growing season on roots, but not in soil, and only under dryland conditions. These seemingly contradictory results both highlight the effect that roots of each genotype have on microorganism populations. Under the experimental conditions of seedling cycling, there was a visible build-up of root debris in the soil in cycles 2 through 4; this debris may have had a greater effect on microorganism populations than roots of growing seedlings. In field culture using annual rotation with soybean, there would have been little or no sorghum debris in the soil at planting, and little root debris would have built-up in the soil during the growing season. Therefore, the rhizosphere appeared to exert a stronger influence. Further research into sorghum genotype-specific rhizosphere microorganism interactions is greatly needed.

Acknowledgements We thank J. Toy for management of field plots and production and maintenance of grain and $\mathrm{P}$. O'Neill for overseeing laboratory and greenhouse operations and assistance with statistical analyses. Mention of trade names or commercial products in this article is solely for the purpose of providing specific information and does not imply recommendation or endorsement by the U.S. Department of Agriculture. This article is in the public domain and not copyrightable. It may be freely reprinted with customary crediting of source.

\section{References}

Andrews S, Pitt JI (1986) Selective medium for isolation of Fusarium species and dematiaceous Hyphomycetes from cereals. Appl Environ Microbiol 51:1235-1238

Audilakshmi S, Aruna C, Solunke RB, Kamatar MY, Kandalkar HG, Gaikwad P, Ganesh Murthy K, Jayaraj K, Ratnavathi CV, Kannababu N, Indira S, Seetharama N (2007) Approaches to grain quality improvement in rainy season sorghum in India. Crop Prot 26:630-641

Awika JM, Rooney LW (2004) Sorghum phytochemicals and their potential impact on human health. Phytochemistry 65:1199-1221

Bachman G, Kinzel H (1992) Physiological and ecological aspects of the interactions between plant roots and rhizosphere soil. Soil Biol Biochem 24:543-552

Bangera MG, Thomashow LS (1999) Identification and characterization of a gene cluster for synthesis of the polyketide antibiotic 2, 4-diacetylphloroglucinol from Pseudomonas fluorescens Q2-87. J Bacteriol 181:3155-3163

Berg G, Smalla K (2009) Plant species and soil type cooperatively shape the structure and function of microbial communities in the rhizosphere. FEMS Microbiol Ecol 68:1-13

Bergsma-Vlami M, Prins ME, Raaijmakers JM (2005) Influence of plant species on population dynamics, genotypic diversity and antibiotic production in the rhizosphere by indigenous Pseudomonas spp. FEMS Microbiol Ecol 52:59-69

Bragulat MR, Martínez E, Castellá G, Cabañes FJ (2004) Selective efficacy of culture media recommended for isolation and enumeration of Fusarium spp. J Food Prot 67:207-211

Castric KF, Castric PA (1983) Method for rapid detection of cyanogenic bacteria. Appl Environ Microbiol 45:701-702

Compant S, Clément C, Sessitsch A (2010) Plant growthpromoting bacteria in the rhizo- and endosphere of plants: their role, colonization, mechanisms involved and prospects for utilization. Soil Biol Biochem 42:669-678

Cook RJ (2007) Management of resident plant growthpromoting rhizobacteria with the cropping system: a review of experience in the US Pacific Northwest. Eur J Plant Pathol 119:255-264

Cowan ST (1974) Cowan and Steel's manual for the identification of medical bacteria. Cambridge University Press, London

Czarnota MA, Paul RN, Dayan FE, Nimbal CI, Weston LA (2001) Mode of action, localization of production, chemical nature, and activity of sorgoleone: a potent PSII inhibitor in Sorghum spp. root exudates. Weed Technol 15:813-825

Das IK, Indira S, Annapurna A, Prabhakar SN (2008) Biocontrol of charcoal rot in sorghum by fluorescent pseudomonads associated with the rhizosphere. Crop Prot 27:1407-1414

de Souza JT, Weller DM, Raaijmakers JM (2002) Frequency, diversity and activity of 2, 4-diacetylphloroglucinolproducing fluorescent Pseudomonas spp. in Dutch takeall decline soils. Phytopathology 93:54-63

Dhuyvetter KC, Thompson CR, Norwood CA, Halvorson AD (1996) Economics of dryland cropping systems in the Great Plains: a review. J Prod Agric 9:216-222 
Doggett H (1988) Sorghum. Longman Scientific \& Technical, Essex

Doran JW, Elliott ET, Paustian K (1998) Soil microbial activity, nitrogen cycling, and long-term changes in organic carbon pools as related to fallow tillage management. Soil Tillage Res 49:3-18

Dubuis C, Keel C, Haas D (2007) Dialogues of root-colonizing biocontrol pseudomonads. Eur J Plant Pathol 119:311-328

Duffy B, Keel C, Défago G (2004) Potential role of pathogen signaling in multitrophic plant-microbe interaction involved in disease protection. Appl Environ Microbiol 70:1836-1842

Dunbar J, White S, Forney L (1997) Genetic diversity through the looking glass: effect of enrichment bias. Appl Environ Microbiol 63:1326-1331

Einhellig FA, Souza IF (1992) Phytotoxicity of sorgoleone found in grain sorghum root exudates. J Chem Ecol 18:1-11

Flores-Vargas RD, O'Hara GW (2006) Isolation and characterization of rhizosphere bacteria with potential for biological control of weeds in vineyards. J Appl Microbiol 100:946954

Funnell DL, Pedersen JF (2006) Reaction of sorghum lines genetically modified for reduced lignin content to infection by Fusarium and Alternaria spp. Plant Dis 90:331338

Funnell-Harris DL, Pedersen JF, Marx DB (2008) Effect of sorghum seedlings, and previous crop, on soil fluorescent Pseudomonas spp. Plant Soil 311:173-187

Garbeva P, van Elsas JD, van Veen JA (2008) Rhizosphere microbial community and its response to plant species and soil history. Plant Soil 302:19-32

Gaudet DA, Major DJ (1986) Factors affecting seedling emergence of sorghum for short-season areas. Plant Dis 70:572-575

Gimsing AL, Bælum J, Dayan FE, Locke MA, Hanefeld Sejerø L, Jacobsen CS (2009) Mineralization of the allelochemical sorgoleone in soil. Chemosphere 76:1041-1047

Hodge A, Berta G, Doussan C, Merchan F, Crespi M (2009) Plant root growth, architecture and function. Plant Soil 321:153-187

Huang L-D, Backhouse D (2005) Induction of defence responses in roots and mesocotyls of sorghum seedlings by inoculation with Fusarium thapsinum and F. proliferatum, wounding and light. J Phytopath 153:522-529

Idris HA, Labuschagne N, Korsten L (2007) Screening rhizobacteria for biological control of Fusarium root and crown rot of sorghum in Ethiopia. Biol Control 40:97-106

Kipe-Nolt JA, Avalakki UK, Dart PJ (1985) Root exudation of sorghum and utilization of exudates by nitrogen-fixing bacteria. Soil Biol Biochem 17:859-863

Landa BB, Mavrodi OV, Raaijmakers JM, McSpadden Gardener BB, Thomashow LS, Weller DM (2002) Differential ability of genotypes of 2, 4-diacetylphloroglucinolproducing Pseudomonas strains to colonize the roots of pea plants. Appl Environ Microbiol 68:3226-3237

Landa BB, Mavrodi DM, Thomashow LS, Weller DM (2003) Interactions between strains of 2, 4-diacetylphoroglucinolproducing Pseudomonas fluorescens in the rhizosphere of wheat. Phytopathology 93:982-994

Landa BB, Mavrodi OV, Schroeder KL, Allende-Molar R, Weller DM (2006) Enrichment and genotypic diversity of
phlD-containing fluorescent Pseudomonas spp. in two soils after a century of wheat and flax monoculture. FEMS Microbiol Ecol 55:351-368

Larkin RP, Hopkins DL, Martin FN (1993) Effect of successive watermelon plantings on Fusarium oxysporum and other microorganisms in soils suppressive and conducive to Fusarium wilt of watermelon. Phytopathology 83:1097-1105

Latour X, Corberand T, Laguerre G, Allard F, Lemanceau P (1996) The composition of fluorescent pseudomonad populations with roots is influenced by plant and soil type. Appl Environ Microbiol 62:2449-2456

Latour X, Philippot L, Corberand T, Lemanceau P (1999) The establishment of an introduced community of fluorescent pseudomonads in the soil and in the rhizosphere is affected by the soil type. FEMS Microbiol Ecol 30:163-170

Leslie JF, Plattner RD, Desjardins AE, Klittich CJR (1992) Fumonisin $\mathrm{B}_{1}$ production by strains from different mating populations of Gibberella fujikuroi (Fusarium section Liseola). Phytopathology 82:341-345

Leslie JF, Zeller KA, Lamprecht SC, Rheeder JP, Marasas WFO (2005) Toxicity, pathogenicity and genetic differentiation of five species of Fusarium from sorghum and millet. Phytopathology 95:275-283

Mavrodi DV, Ksenzenko VN, Bonsall RF, Cook RJ, Boronin AM, Thomashow LS (1998) A seven-gene locus for synthesis of phenazine-1-carboxylic acid by Pseudomonas fluorescens 2-79. J Bacteriol 180:2541-2548

Mazzola M, Gu Y-H (2000) Impact of wheat cultivation on microbial communities from replant soils and apple growth in greenhouse trials. Phytopathology 90:114-119

Mazzola M, Gu Y-H (2002) Wheat genotype-specific induction of soil microbial communities suppressive to disease incited by Rhizoctonia solani anastomosis group (AG)-5 and AG-8. Phytopathology 92:1300-1307

Mazzola M, Cook RJ, Thomashow LS, Weller DM, Pierson LS III (1992) Contribution of phenazine antibiotic biosynthesis to the ecological competence of fluorescent pseudomonads in soil habitats. Appl Environ Microbiol 58:2616-2624

Mazzola M, Fujimoto DK, Thomashow LS, Cook RJ (1995) Variation in sensitivity of Gaeumannomyces graminis to antibiotic produced by fluorescent Pseudomonas spp. and effect on biological control of take-all of wheat. Appl Environ Microbiol 61:2554-2559

Mazzola M, Funnell DL, Raaijmakers JM (2004) Wheat cultivar-specific selection of 2, 4-diacetylphloroglucinolproducing fluorescent Pseudomonas species from resident soil populations. Microb Ecol 48:338-348

Meharg AA, Wyatt CL, Thompson IP, Bailey MJ, Ellis RJ, Maguire N (1998) Response of soil microbial biomass to 1, 2-dichlorobenzene addition in the presence of plant residues. Environ Toxicol Chem 8:1462-1468

Muriithi LM, Claflin LE (1997) Genetic variation of grain sorghum germplasm for resistance to Pseudomonas andropogonis. Euphytica 98:129-132

Murillo-Williams A, Munkvold GP (2008) Systemic infection by Fusarium verticillioides in maize plants grown under three temperature regimes. Plant Dis 92:1695-1700

Nash SM, Snyder WC (1962) Quantitative estimations by plate counts of propagules of the bean root rot Fusarium in field soils. Phytopathology 52:567-572 
Nelson PE, Toussoun TA, Marasas WFO (1983) Fusarium species: An illustrated manual for identification. The Pennsylvania State University Press, University Park

Nimbal CI, Pedersen JF, Yerkes CN, Weston LA, Weller SC (1996) Phytotoxicity and distribution of sorgoleone in grain sorghum germplasm. J Agric Food Chem 44:1343-1347

Petrovic T, Walsh JL, Burgess LW, Summerell BA (2009) Fusarium species associated with stalk rot of grain sorghum in the northern grain belt of eastern Australia. Australas Plant Pathol 38:373-379

Picard C, Bosco M (2006) Heterozygosis drives maize hybrids to select elite 2, 4-diacetylphloroglucinol-producing Pseudomonas strains among resident soil populations. FEMS Microbiol Ecol 58:193-204

Picard C, Bosco M (2008) Genotypic and phenotypic diversity in populations of plant-probiotic Pseudomonas spp. colonizing roots. Naturwissenschaften 95:1-16

Picard C, Baruffa E, Bosco M (2008) Enrichment and diversity of plant-probiotic microorganisms in the rhizosphere of hybrid maize during four growth cycles. Soil Biol Biochem 40:106-115

Pratt RG, Janke GD (1980) Pathogenicity of three species of Pythium to seedlings and mature plants of grain sorghum. Phytopathology 70:766-771

Raaijmakers JM, Weller DM, Thomashow LS (1997) Frequency of antibiotic-producing Pseudomonas spp. in natural environments. Appl Environ Microbiol 63:881-887

Rai KN, Murty DS, Andrews DJ, Bramel-Cox PJ (1999) Genetic enhancement of pearl millet and sorghum for the semi-arid tropics of Asia and Africa. Genome 42:617-628

Raju NS, Niranjana SR, Janardhana GR, Prakash HS, Shekar Shetty H, Mathur SB (1999) Improvement of seed quality and field emergence of Fusarium moniliforme infected sorghum seeds using biological agents. J Sci Food Agric 79:206-212

Reddy KN (2001) Glyphosate-resistant soybean as a weed management tool: opportunities and challenges. Weed Biol Manag 1:193-202

Rezzonico F, Zala M, Keel C, Duffy B, Moënne-Loccoz Y, Défago $G$ (2007) Is the ability of biocontrol fluorescent pseudomonads to produce the antifungal metabolite 2,4diacetylphloroglucinol really synonymous with higher plant protection? New Phytol 173:861-872

Roth CM, Shroyer JP, Paulsen GM (2000) Allelopathy of sorghum on wheat under several tillage systems. Agron J 92:855-860

Sanguin H, Sarniguet A, Gazengel K, Moënne-Loccuz Y, Grundmann GL (2009) Rhizosphere bacterial communities associated with disease suppressiveness stages of take-all decline in wheat monoculture. New Phytol 184:694-707

Sarath G, Mitchell RB, Sattler SE, Funnell D, Pedersen JF, Graybosch RA, Vogel KP (2008) Opportunities and roadblocks in utilizing forages and small grains for liquid fuels. J Ind Microbiol Biotechnol 35:343-354

SAS (2000-2004) SAS 9.1.3 help and documentation. SAS Institute, Inc, Cary

Semenov AM, van Bruggen AHC, Zelenev VV (1999) Moving waves of bacterial populations and total organic carbon along roots of wheat. Microb Ecol 37:116-128

Simon A, Ridge EH (1974) The use of ampicillin in a simplified selective medium for the isolation of fluorescent psuedomonads. J Appl Bacteriol 37:459-460

Smith CW, Frederiksen RA (2000) Sorghum: origin, history, technology and production. Wiley, New York

Sørensen J, Haubjerg Nichaisen M, Ron E, Simonet P (2009) Molecular tools in rhizosphere microbiology-from single-cell to whole-community analysis. Plant Soil 321:483-512

Svercel M, Christen D, Moënne-Loccoz Y, Duffy B, Défago G (2009) Effect of long-term vineyard monoculture on rhizosphere populations of pseudomonads carrying the antimicrobial biosynthetic genes phlD and/or hcnAB. FEMS Microbiol Ecol 68:25-36

Tesso TT, Claflin LE, Tuinstra MR (2005) Analysis of stalk rot resistance and genetic diversity among drought tolerant sorghum genotypes. Crop Sci 45:645-652

Troxler J, Zala M, Natsch A, Moënne-Loccoz Y, Défago G (1997) Autecology of the biocontrol strain Pseudomonas fluorescens CHAO in the rhizosphere and inside roots at later stages of plant development. FEMS Microbiol Ecol 23:119-130

Venne J, Beed F, Avocanh A, Watson A (2009) Integrating Fusarium oxysporum f. sp. strigae into cereal cropping systems in Africa. Pest Manag Sci 65:572-580

Wang C, Ramette A, Panjasamarnwong P, Zala M, Natsch A, Moënne-Loccoz Y, Défago G (2001) Cosmopolitan distribution of phlD-containing dicotyledonous crop-associated biocontrol pseudomonads of worldwide origin. FEMS Microbiol Ecol 37:105-116

Waniska RD, Venkatesha RT, Chandrashekar A, Krishnaveni S, Bejosano FP, Jeoung J, Jayaraj J, Muthukrishnan S, Liang GH (2001) Antifungal proteins and other mechanisms in the control of sorghum stalk rot and grain mold. J Agric Food Chem 49:4732-4742

Weidenhamer JD (2005) Biomimetic measurement of allelochemical dynamics in the rhizosphere. J Chem Ecol 31:221-236

Zhang L, Xu Z (2008) Assessing bacterial diversity in soil. J Soils Sediments 8:379-388

Zuberer D (1994) Recovery and enumeration of viable bacteria. In: Weaver R (ed) Methods of soil analysis. Part 2, microbiological and biochemical properties. Soil Science Society of America book series; no; 5. Soil Science Society of America, Madison, pp 119-144 